\title{
5-Azacytidine: A Promoter of Epigenetic Changes in the Quest to Improve Plant Somatic Embryogenesis
}

\author{
Pedro Osorio-Montalvo ${ }^{(\mathbb{B}}$, Luis Sáenz-Carbonell and Clelia De-la-Peña * (]) \\ Unidad de Biotecnología, Centro de Investigación Científica de Yucatán, Calle 43 No. 130 x 32 y 34, Col. \\ Chuburná de Hidalgo, 97205 Mérida, Yucatán, Mexico; jacket_147@hotmail.com (P.O.-M.); \\ vyca@cicy.mx (L.S.-C.) \\ * Correspondence: clelia@cicy.mx; Tel.: +52-999-942-8330
}

Received: 25 September 2018; Accepted: 10 October 2018; Published: 16 October 2018

\begin{abstract}
Somatic embryogenesis (SE) is a widely studied process due to its biotechnological potential to generate large quantities of plants in short time frames and from different sources of explants. The success of SE depends on many factors, such as the nature of the explant, the microenvironment generated by in vitro culture conditions, and the regulation of gene expression, among others. Epigenetics has recently been identified as an important factor influencing SE outcome. DNA methylation is one of the most studied epigenetic mechanisms due to its essential role in gene expression, and its participation in SE is crucial. DNA methylation levels can be modified through the use of drugs such as 5-Azacytidine (5-AzaC), an inhibitor of DNA methylation, which has been used during SE protocols. The balance between hypomethylation and hypermethylation seems to be the key to SE success. Here, we discuss the most prominent recent research on the role of 5-AzaC in the regulation of DNA methylation, highlighting its importance during the SE process. Also, the molecular implications that this inhibitor might have for the increase or decrease in the embryogenic potential of various explants are reviewed.
\end{abstract}

Keywords: somatic embryogenesis; DNA methylation; 5-Azacytidine; epigenetics; hypomethylation; plant tissue culture; 2,4-dichlorophenoxyacetic acid (2,4-D); in vitro

\section{Introduction}

With more than seven billion people to feed, the need for food and energy has become an urgent problem to resolve. The worldwide population needs healthier and safer food, and one way to do this is by increasing crop production. Plant tissue culture (PTC) is a set of biotechnological techniques to establish, maintain and multiply cells, tissues, organs and even whole plants under controlled and aseptic conditions to generate more plants in a shorter period than conventional methods. PTC has been used with great success in the agricultural industry to produce fruit, ornamental and medicinal plants, and even forest-dwelling species. Therefore, PTC represents the most promising area of application today and offers a perspective for the future [1].

Two of the most common PTC methods for the regeneration of plant structures are organogenesis and somatic embryogenesis (SE). Organogenesis refers to the generation of monopolar structures (shoots, leaves or roots) that may arise directly from the meristem or indirectly from the undifferentiated cell masses called callus [2]. On the other hand, SE is a process that generates bipolar structures (shoot apical meristem and root apical meristem), similar to a zygotic embryo, developed from a non-zygotic cell with no vascular connection to the original tissue [3,4]. Both organogenesis and SE can be obtained directly or indirectly; it means that organs or somatic embryos can be developed directly from the explant or the callus, respectively [5]. Regardless of the morphogenic pathway (direct or indirect), SE can produce genetically identical individuals to the donor of the explant, which is a significant 
advantage in when controlling the quality and selection of plants [6]. It is important to highlight that for study purposes, and from an economic point of view, it is necessary to have the capacity to differentiate between different callus types, mainly embryogenic callus (callus that generates somatic embryos [7]) and non-embryogenic callus (callus that does not generate somatic embryos). By being able to identify the embryogenic callus from the non-embryogenic ones, we avoid selecting callus under in vitro conditions that will not generate the necessary number of somatic embryos.

Thanks to the study of SE, it has been possible to isolate genes, proteins, and metabolites involved in the process of cell differentiation. These discoveries have led to a better understanding of differentiation, as well as the genetic mechanisms involved in the transition from one stage to the next. It has highlighted the importance of continuing to study SE in all aspects (biochemical, genetic and transcriptomic) to accelerate the discovery, isolation, and characterization of genes involved in different cellular processes [8-10].

SE can be triggered in the explant by applying specific conditions such as stress (mechanical, osmotic, chemical, heavy metals, hypoxia, temperature and ultraviolet light) as well as by both endogenous and exogenous plant growth regulator (PGR) levels [11-13]. The PGR most used to induce SE is the exogenous auxin 2,4-Dichlorophenoxyacetic acid (2,4-D) [14]. The different conditions (endogenous or exogenous to the explant) can influence the metabolic patterns, gene expression and epigenetic mechanisms (DNA methylation, histone modifications, and microRNAs) of the explant, provoking a cell (or a group of cells) to change its nature (Figure 1). A somatic cell can develop into a totipotent, undifferentiated and embryogenic cell and the embryogenic cell can generate all the cells forming a somatic embryo, which later becomes a complete and functional plantlet (Figure 1).

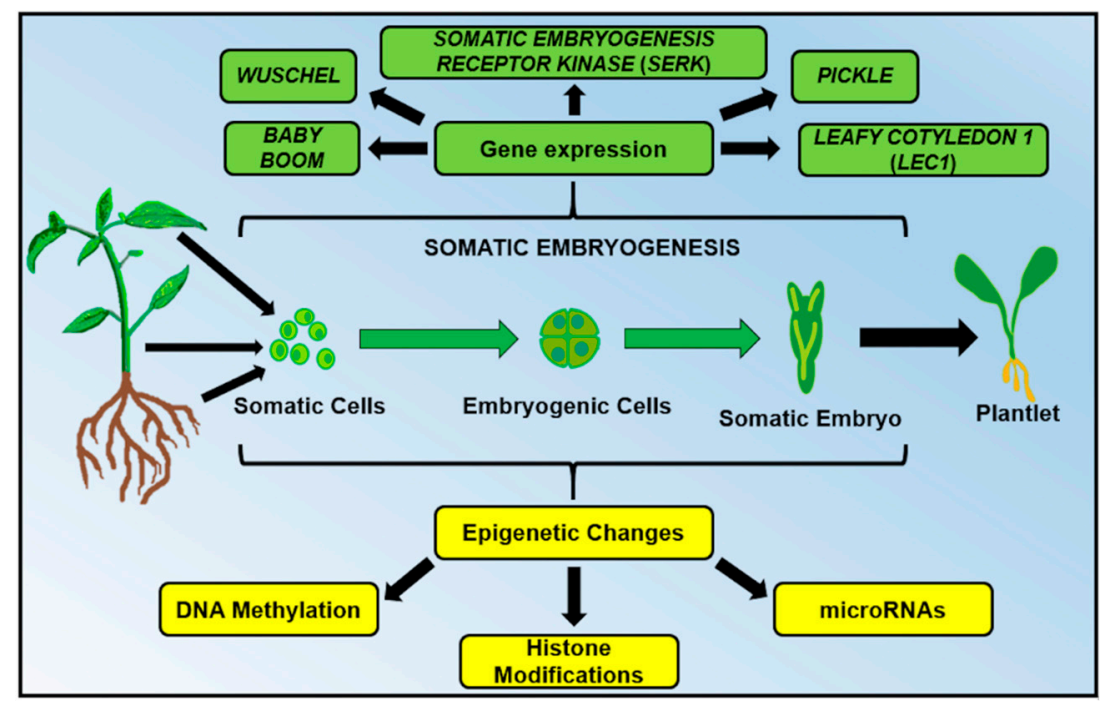

Figure 1. In plant somatic embryogenesis, genetic (green) and epigenetic (yellow) mechanisms induce the development of embryogenic cells from any explant (cells isolated from the leaves, shoots or roots). Due to the totipotentiality properties of plant cells, a group of embryogenic cells can develop into a complete and functional plantlet.

The SE process can be divided into two significant steps: induction and development (Figure 2). The induction stage has three phases: dedifferentiation, totipotency, and acquisition of the embryogenic competence [15]. In the dedifferentiation step, mature explant cells lose their specific fate to become meristematic cells. In the totipotency step, the cells acquire the potential to generate any plant cell [16]. In the last step, the acquisition phase of embryogenic competence, the cells reach a state of somatic-embryogenic transition and only require a minimum exogenously applied stimulus to become an embryogenic cell [17]. Morphologically, competent cells already show similar characteristics to those in meristematic cells or zygotes, such as small size and rounded shape with abundant 
cytoplasm and small vacuoles [18]. Next follows the second major stage of the SE process, in which the establishment of the first proembriogenic phases initiates with the transition of the embryogenic forms. These forms are different in dicotyledons and monocotyledons. For instance, in dicotyledonous plants, the embryogenic structures are globular, heart-shaped, torpedo and cotyledonar, while those of monocotyledonous plants are globular, scutellar and coleoptilar (Figure 2).

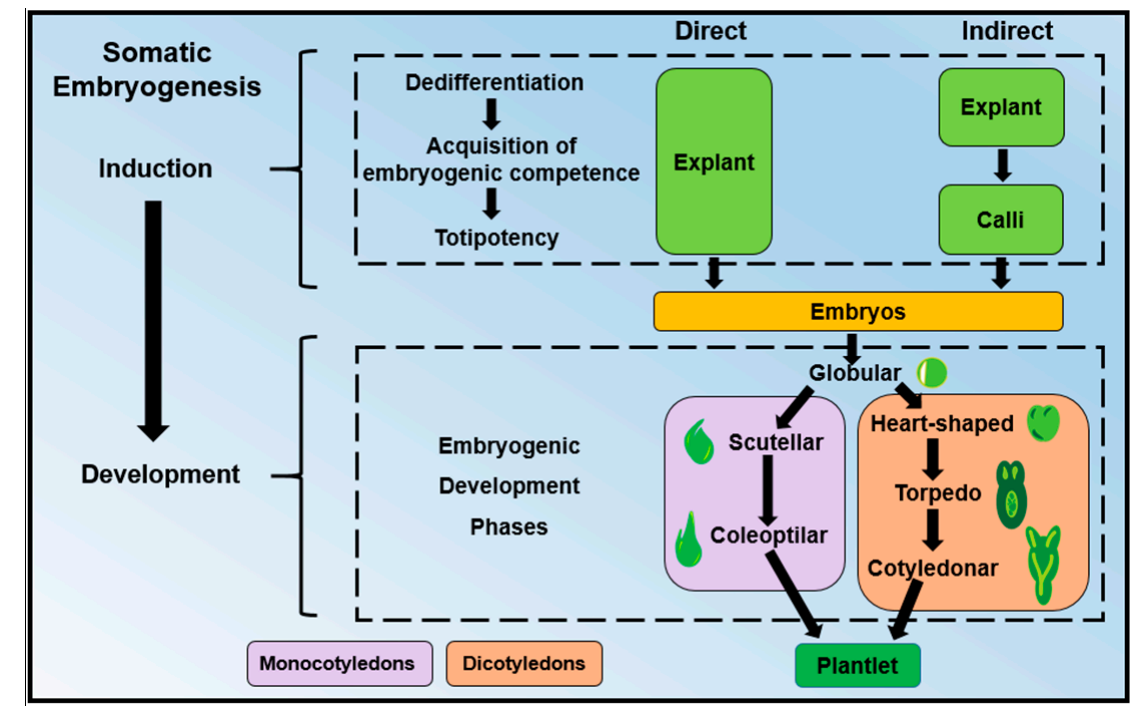

Figure 2. Differences between direct somatic embryogenesis (SE) and indirect SE during the induction and developmental stages in dicotyledonous and monocotyledonous plants.

In recent years, numerous reports have demonstrated that $\mathrm{SE}$ is a process strongly regulated by epigenetic mechanisms (DNA methylation, posttranslational modifications of histones and miRNAs), which induce chromatin remodeling $[7,11,19]$. DNA methylation and histone modification are epigenetic changes that can reorganize chromatin architecture during the in vitro culture of plants $[20,21]$. Since the 1980 's, it has been proposed and reported that embryogenic capacity could be conditioned by DNA methylation levels [22]. Currently, it is known that DNA methylation plays an essential role in the regulation of gene expression during development. Methylation states in the DNA, resulting from in vitro cultures, are often related to the control of SE and the regeneration process through the modulation of gene expression $[19,23]$. By changing the methylation profile, it is possible to alter gene expression, and this can be applied to produce a large number of high-quality plants or to improve the agronomic characteristics leading to the improvement of a crop [24]. By understanding how methylation alterations influence the acquisition of the developmental cell fate during in vitro cultures, we would be able to develop new strategies to enhance the embryogenic capability and totipotency in recalcitrant plant species and genotypes.

As early as the 1980s, an essential role in the control of gene expression was attributed to 5-methylcytosine [25]; thereafter, the focus was on molecular analogs to methyl derivatives of cytosine such as 5-Azacytidine (5-AzaC). 5-AzaC was first used as an anticancer agent, acting as an analog of cytidine and incorporated into DNA, where, due to the nitrogen at the $5^{\prime}$-position of the pyrimidine ring, it could not be methylated [26,27]. The first pieces of evidence that 5-AzaC could induce the expression of silenced genes was carried out on transformed avian and animal virus cell lines. It was observed that when the animal cells (different tissues of mouse and chicken) were treated with this drug, DNA demethylation was detected a short time later (48-96 h) [28-30]. At that time, it was suggested that 5-AzaC was incorporated into DNA, causing methylation to be inhibited and positively affecting gene expression and differentiation [26]. However, there is evidence that this analog might be incorporated into DNA to cause demethylation and, in the first round of replication, lead to the appearance of hemimethylated DNA. Only after the second round of DNA replication 
do completely unmethylated strands appear through the action of the methylation maintenance system. In fact, a 5-AzaC residue incorporated into DNA leads to vast stretches of DNA becoming unmethylated, apparently due to long-term inhibition of the 5-DNA-methyltransferase enzymes and its mode of processing action $[26,31,32]$. There are other DNA hypomethylating analogs such as ethionine, 2-amino-5-ethoxycarbonyl-pyrimidine-4 (3H) (ECP) [21], and zebularine [33]. Currently, the most widely used and studied hypomethylating drug is $5-\mathrm{AzaC}$, and very interesting studies are being carried out to study its effects and the relationship it has on the expression of genes that are important for the SE process [34]. In this review, we will discuss the most recent and important works that have used 5-AzaC to modify the methylation patterns in SE protocols to increase the embryogenic potential and at the same time understand the effect of methylation levels on this process.

\section{DNA Methylation: A Key Player During Somatic Embryogenesis}

It is widely known that embryogenic potential is higher in explants obtained from young tissue constituted mostly of cells with a low level of differentiation, such as zygotic embryos or meristems, unlike other tissues composed of well-differentiated cells such as fundamental, conduction or epidermic tissues [4,35-37]. A couple of years ago, it was revealed that the state of differentiation of plant tissues is strongly controlled by DNA methylation [38], so that the embryogenic or non-embryogenic response between both types of tissues could be determined epigenetically.

DNA methylation is an epigenetic mechanism that plays critical roles in genome integrity, genomic imprinting, $\mathrm{X}$ chromosome inactivation, suppression of transposons and retroviruses, and gene expression [39-43]. DNA methylation occurs after DNA synthesis, and it is catalyzed by enzymes known as DNA cytosine methyltransferases (DCMTases). DCMTases transfer a methyl group of the S-adenosyl-L-methionine molecule to the carbon $5^{\prime}$ of the pyrimidine ring of the cytosines. In mammals, this methylation occurs only in cytosines adjacent to guanines (CpG) [44]. However, in plants, the methylation not only occurs at the $\mathrm{CpG}$ sites but also in the symmetric $\mathrm{CpHpG}$ and asymmetric $\mathrm{CpHpH}$ sequences (where $\mathrm{H}$ is $\mathrm{A}$, $\mathrm{T}$ or $\mathrm{C}$ ) [45]. Based on sequence homology within the enzyme's C-terminal catalytic domains, most DCMTases can be grouped into four distinct families, omitting fungal DCMTases [46]. Plants have four classes of DCMTases: Methyltransferase (MET), Domains Rearranged Methyltransferase (DRM), DNA Nucleotide Methyltransferase 2 (DNMT2) and Chromomethylase (CMT, appearing to be unique to plants), while other eukaryotic organisms have only two or three classes [21]. Additionally, there are two types of methylation: maintenance: (1) this occurs in hemimethylated sites, and is inherited from generation to generation and (2) de novo, which arises spontaneously in places where there was no methylation before [47].

MET1 (DNMT1, ortholog in animals) catalyzes both maintenance and de novo methylation at $\mathrm{CpG}$ sites, while that $\mathrm{CMT3}$ catalyzes maintenance methylation at $\mathrm{CpHpG}$ and $\mathrm{CpHpH}$ sites [48-51]. In addition, DRM2 (DNMT3A, ortholog in animals) catalyzes de novo methylation at $\mathrm{CpG}, \mathrm{CpHpG}$ and $\mathrm{CpHpH}$ sites, and is related to the RdDM mechanism—RNA-directed DNA methylation [41,49]. It has been reported that although Arabidopsis met 1 mutant plants are viable, they are entirely lacking in CpG methylation [41,45,52-54]. DRM2 and DNMT3A structures are not identical to each other, and yet the overall folding is similar in both enzymes, which could explain the structure's conservation in its functions in both plants and animals [43]. The fact that the plant-only DRM2 contains a rearrangement similar to a DNMT3A in its catalytic domain suggests that this rearrangement may have occurred during the early stages of plant evolution [55]. In Arabidopsis thaliana, the impact of DNA methylation on SE was analyzed [34], and it was found that a decrease in global DNA methylation (GDM) during SE contrasted with the positive regulation of the genes MET1 and CMT3 that codify DNA methylases, and the down-regulation of genes ROS1, DME and DML2 (DNA demethylases). Therefore, the level of GDM seemed to correlate with the transcriptional activity of the coding genes of DNA methylases/demethylases. 


\subsection{Hypomethylation Promotes Embryogenic Capacity}

DNA methylation plays a vital role in cell dedifferentiation, redifferentiation and the growth and development of plants [56]. In SE, DNA methylation regulates and maintains the gene expression programs of several genes; however, due to the previously reported critical implications for the embryogenic process in plants, a group of genes has been especially studied (Figure 1): Leafy Cotyledon 1 (LEC1), Wuschel (WUS), Somatic Embryogenesis Receptor Kinase (SERK), Pickle (PKL) and Baby Boom (BBM) $[20,23,57]$. For instance, the manipulation of methylation in specific genes, such as LEC1 [58] and Wuschel (WUS) [59], drastically affects the regulation of the differentiation of plant explants. In the SE process of Coffea canephora, it was reported that between 21 and 28 days after induction (dai) there was a reduction of GDM that coincided with the formation of the first proembryogenic masses. Subsequently, a gradual increase of GDM was observed between 28 and 49 dai. During this same period, somatic embryos appeared and developed from the globular stage to the torpedo stage. Finally, the pronounced increase in GDM between 49 and 56 dai coincided with the transition from somatic embryos in the torpedo phase to the cotyledon phase. These observations support the idea that a decrease in global DNA methylation could be a critical step in triggering cell dedifferentiation and acquiring cell totipotency in somatic cells. We can also suggest that the epigenetic cell reprogramming through dynamic changes in DNA methylation promotes the embryogenic route and the development of somatic embryos [60].

In Boesenbergia rotunda (L.) Mansf., the expression of the SERK, BBM, LEC2 and WUS genes was studied, and also the gene-specific methylation by bisulfite sequencing data of these genes. Based on these results, it was suggested that relatively higher expression and lower level of DNA methylation of SERK, BBM, LEC2, and WUS are associated with somatic embryogenesis and plant regeneration [23]. Recently it was reported in cotton that the inhibition of methylation by the use of zebularine activated the transcription of hormone-related genes (IAA14, CKX6, LBD1/3, LOX1, CRF4.1) and may promote SE [33].

In Theobroma cacao, it was reported that the methylation profiles of explants with a lower level of differentiation that generated embryogenic callus (staminoids) were different from the more differentiated tissue profiles (leaves of the explant tree and regenerated plants). It was speculated that these differences could be in the states of differentiation [61]. This information suggests that less differentiated tissues have lower levels of methylation, and are more likely to generate somatic embryos, than those with a higher level of differentiation and higher DNA methylation. A similar hypothesis was formulated for Daucus carota, in which it was found that non-embryogenic vacuolar cells contained the highest levels in GDM $(25.7 \%)$, while meristematic cells (embryogenic tissue) had lower GDM (21.9\%) [62]. This work reported that after differentiation and during aging and cell growth, the leaves become more methylated, going from $18.5 \%$ in the seedling to $24.0 \%$ in the adult plant. Furthermore, it seems that the relationship between hypomethylation and embryogenic potential happens not only in plants but also in trees. Such is the case of three embryogenic cell lines of Pinus nigra Arn. ssp. Austriaca with different embryogenic potentials (high, medium or low) [63]. It was found that the line considered to be the most embryogenic (with the capacity to develop the whole embryogenic program and produce plants) showed the lowest levels of DNA methylation, while the least embryogenic line had the highest level of methylation. In another woody species, Quercus alba, the methylation levels in embryogenic and non-embryogenic tissues were analyzed [64] and the results were similar to those found in P. nigra [63]. The percentage of DNA methylation was significantly lower in embryogenic cells than in non-embryogenic cells, which suggested that DNA methylation decreased during induction of SE. Differences in levels of GDM that depended on the type of tissue (embryogenic or non-embryogenic) have also been reported [64,65]. The analysis showed a lower GDM in somatic embryos, unlike non-embryogenic cell nuclei. Different GDM levels depending on the embryogenic potential suggested that they could be used as markers of early embryogenesis [64]. Furthermore, in Castanea sativa [66], it was reported that only the fertilized ovules suffer a decrease in DNA methylation, while the ovules that are not fertilized do not experience this reduction in DNA 
methylation. Only the ovules that hypomethylated after fertilization are capable of generating zygotic embryos, which suggests that hypomethylation is a pre-requirement to activate the development of zygotic embryos.

Taken together, these reports prompt the hypothesis that if we can find a strategy to manipulate GDM levels, we could improve embryogenic induction in species that have a high level of GDM and low embryogenic potential. Global DNA methylation could be used not only as a marker for the embryogenic capacity of the explant but also to monitor the gradual changes of embryo development. In carrot, globular somatic embryos generate when a reduction in GDM occurs, and this reduction starts to increase during the development and maturation of the somatic embryos [65]. Also in carrot, but using a different system, it was reported that the methylation levels decrease during the change from the somatic to the embryogenic program and in the early stages of the embryos [67]. In later stages of the process, DNA methylation gradually increases. Furthermore, in C. sativa, the increase in GDM was also reported during the development of the embryos [66]. Another study found that low levels of GDM were related to the emergence of the proembryogenic mass in C. canephora during the SE process, which was also strongly related to the expression of genes involved in cell differentiation [60].

Based on these findings about DNA methylation and SE response, it is possible that more species follow the same pattern of the dynamics of DNA methylation in different tissues during the process of SE in plants (Figure 3). In summary, it is known that the level of methylation in explants with higher embryogenic potential (usually undifferentiated tissues such as meristems, zygotic or anther embryos) is lower than in explants with less or no embryogenic potential (differentiated plant organs such as stems, roots or leaves). In other words, the embryogenic potential of an explant is inversely proportional to the DNA methylation and the level of tissue differentiation (Figure 3A). Furthermore, the evidence shows that the level of methylation in embryogenic callus is lower than in non-embryogenic callus (Figure 3B) and, when the explants are established in the culture medium (before the induction process), GDM is relatively low. During the induction process, the lowest GDM is observed around the time of the appearance of the first proembryogenic masses/structures. In proembryos and early somatic embryos (preglobular, globulars) there is a gradual increase of GDM. When the embryos are in the late stages (heart and cotyledonar), the GDM is higher and when the embryos germinate and develop into seedlings, the highest level of GDM is achieved (Figure 3C).

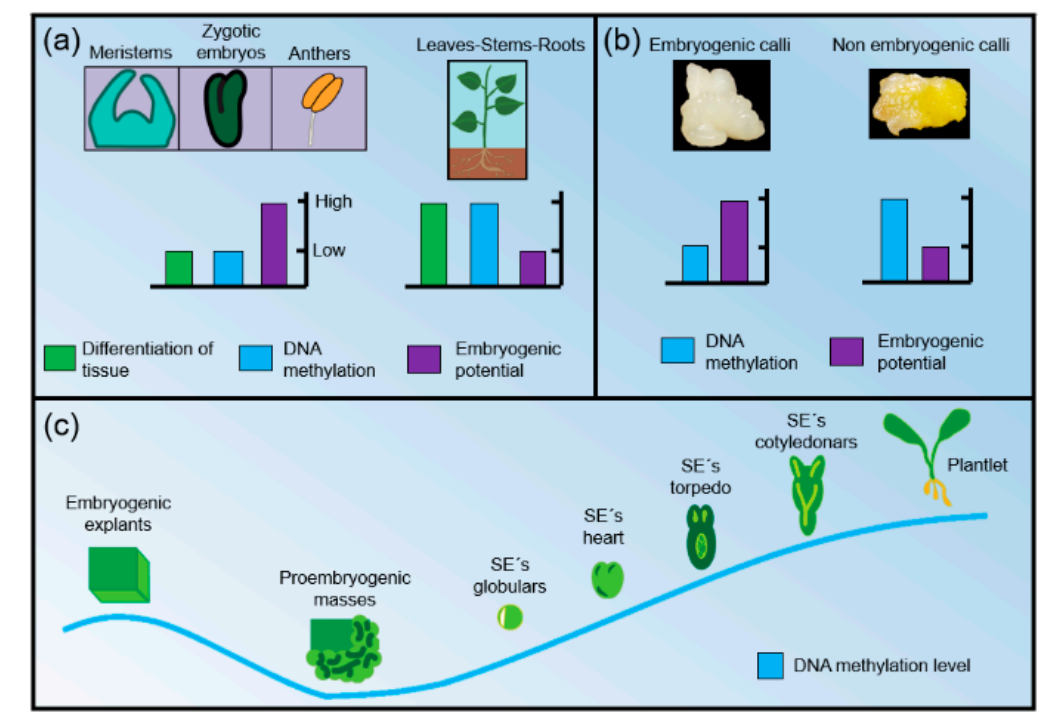

Figure 3. (A) Relations between levels of cell differentiation, DNA methylation and embryogenic potential between different kinds of plant tissues used as explants; (B) differences in DNA methylation and embryogenic potential between embryogenic and non-embryogenic callus; (C) dynamics of DNA methylation levels throughout the SE process. 


\subsection{The Role of Auxins in DNA Methylation}

Several studies have described the relationship between DNA methylation and embryogenic responses, which in some cases depend on the in vitro culture conditions, but mostly are related to the kind and concentration of PGR added to the culture medium $[20,65,68,69]$. Auxins, especially 2,4-D, are an essential PGR used at the beginning of the SE process. They are known to induce many molecular and metabolic changes that promote the reactivation of cell division and proliferation. 2,4-D is essential in most SE protocols and cannot be removed early in the process; it has been used alone or combined with other PGRs in more than $65 \%$ of the protocols for inducing SE [14]. The effect of type and concentration of auxins on genome-wide methylation levels has been studied in several embryogenic cultures. In D. carota, it was found that an increase in 2,4-D concentration promotes higher GDM levels [65]. In this work it was reported that SE does not occur when 2,4-D is in the culture medium; however, when it is removed from the medium, the development of somatic embryos is stimulated [65]. A similar process happens in C. canephora, but with a different auxin; in this case the plantlets used as a source of explants require a pretreatment period with naphthaleneacetic acid (NAA) and kinetin for two weeks, after which the auxin is removed from the media in order to induce SE [70].

It has been suggested that 2,4-D can modify GDM in SE by the accumulation or depletion of S-adenosylmethionine (SAM) and S-adenosylcysteine (SAH) [69]. The removal of 2,4-D produces a reduction in ethylene production (Figure 4), which increases the accumulation of SAM and the SAM/SAH ratio, which in turn causes an increase in DNA methylation [69]. It was observed that an increase in the SAM level is needed to facilitate an increase in the SAM-consuming processes that are necessary for the development of somatic embryos (e.g., SAM-dependent methylations and polyamine biosynthesis), so the availability of SAM may be necessary for the acquisition of embryogenic potential and, later, for the control of embryonic development [71]. Recently, other protocols of SE have reported similar requirements for 2,4-D; e.g., in the date palm [72,73], Kalopanax septemlobus [74] and Coriandrum sativum [75].

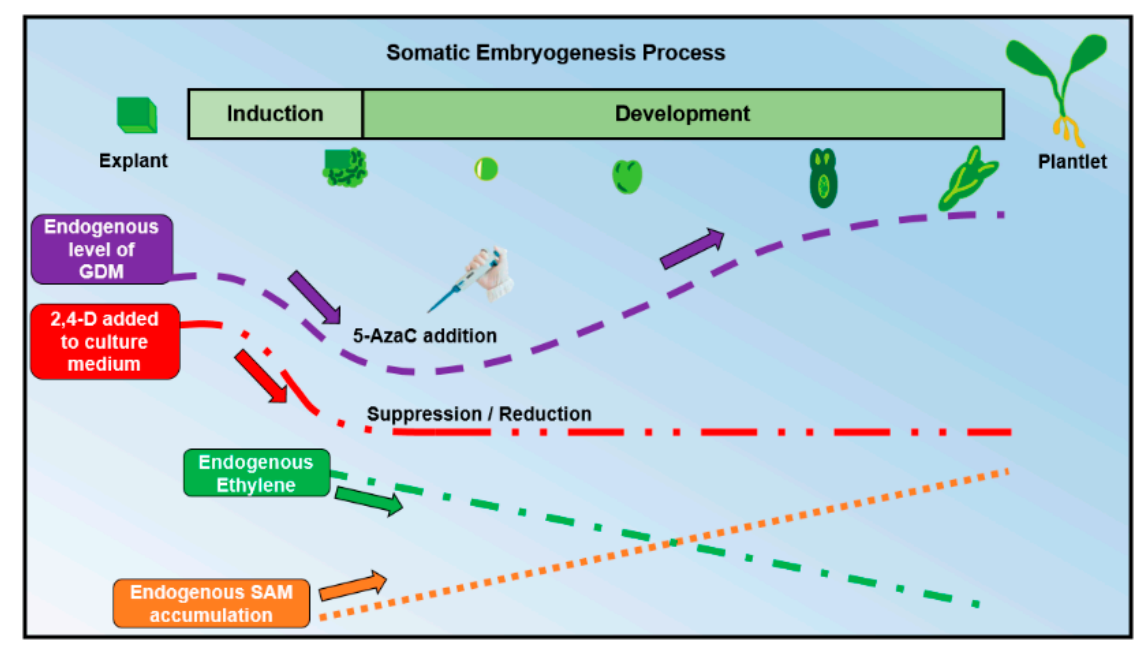

Figure 4. Global DNA methylation, SAM and ethylene dynamics when 2,4-D and 5-AzaC are added to the culture media during the SE process. SAM: S-adenosylmethionine. 2,4-D: 2,4-Dichlophenoxyacetic acid. GDM: global DNA methylation. The purple arrow represents the dynamics of GDM. The red arrow represents the amount of 2,4-D added into the culture medium. The green arrow represents the decrease in endogenous ethylene reported in different studies. The orange arrow represents the increase in the accumulation of endogenous SAM reported in different studies.

It is likely that the effects observed in the increase or decrease of the embryogenic potential are caused by the up-regulation of genes that encode the transcription factors (TFs) that have a regulatory function in auxin biosynthesis, as reported in the explants of Arabidopsis thaliana treated 
with trichostatin A, an inhibitor of histone deacetylases [76]. Inhibition of methylation caused by 5-AzaC might also alter the expression of TFs involved in auxin or any other PGR biosynthesis, degradation or signaling pathway.

\section{The Use of 5-Azacytidine During Somatic Embryogenesis}

5-AzaC has been used in many protocols of SE for different species of plants (Table 1), among which there have been cases where the embryogenic response has been unquestionably positive, such as in Pinus pinaster, Brassica napus, Hordeum vulgare and Theobroma cacao. In P. pinaster (Ait.), embryonal masses were exposed to 5-AzaC in different concentrations and durations. When embryonal masses were exposed for 9 days to 5 -AzaC, their growth was inversely proportional to the increase in drug concentration. The highest amounts of somatic embryos were obtained at levels of 10 and $15 \mu \mathrm{M}$ of 5-AzaC [77]. In Brassica napus and Hordeum vulgare [78], induction of embryos increased with four days of treatment with 5-AzaC $(2.5 \mu \mathrm{M})$. Similar effects were found in both species, indicating that DNA demethylation promotes the reprogramming of gene expression, acquisition of totipotency and the initiation of embryogenesis in microspores. Embryo differentiation probably requires higher levels of GDM or de novo DNA methylation to acquire a specific pattern of gene expression. In Theobroma cacao (cocoa), the embryogenic potential and GDM were analyzed during the long-term secondary SE use as explants from young somatic embryos (12 months of age), aged (36 months of age) and extended SE (39 months), and higher methylation levels were detected in aged somatic embryos [79]. High levels of GDM in long-term SE in cocoa induced a decrease in embryogenic potential, but this decrease was reversed by the addition of 5 -AzaC.

Although 5-AzaC has been proven to have positive effects on SE, both the amount and the stage when it is applied need to be taken into consideration to avoid damaging results on the embryogenic process. In C. canephora, it was found that when $5-\mathrm{AzaC}$ was added to the culture media in the first seven days of the SE process, the embryogenic response was inhibited [60]. However, when 5-AzaC was added after 21 days of induction, positive effects were observed. The results obtained in this work suggest that the impact of 5-AzaC (mainly at $20 \mu \mathrm{M}$ ) added at day 21 dpi not only synchronized the embryogenic process but also reduced the maturation of the embryo. In hybrid larch (Laris $\mathrm{x}$ euroleis), the addition of 5-AzaC $(100 \mu \mathrm{M})$ after one week, in multiplication medium, decreased the levels of GDM (from $45.8 \%$ to $41.3 \%$ ) and significantly reduced the relative growth rate of embryonal masses (from 6.3 to 1.8). The value of relative growth rate was obtained by the following formula: $\left(\left(F W_{t+1}\right.\right.$ $\left.\left.-F W_{t}\right) / F W_{t}\right)$, where $F W$ is fresh weight and $t$ is time [98]. In another conifer, Picea omorika, 5-AzaC $(12.3 \mu \mathrm{M})$ was added one week before the transfer of the embryogenic explant from the medium of maturation to the proliferation medium [102]. In this case, the numerical values of differential methylation of cytosines (DMC) were obtained by the program 'RAPD distance 1.04 ' and using the algorithm for estimating DNA sequence divergence based on a comparison of restriction endonuclease digests. The DMC value of medium with 5-AzaC (0.267) decreased to $19 \%$ compared to the same medium without 5-AzaC (0.323). However, at the end of the experiment, the total number of embryos developed was not significantly different between the control and the treatment with 5-AzaC (181 and 189, respectively).

Recently, a completely inhibitory effect on SE was reported in the model plant $A$. thaliana [34]. In this study, it was reported that in the treatments with 5-AzaC $(10 \mu \mathrm{M})$ explants produced massively non-embryogenic callus, while in the control (without 5-AzaC) the formation of somatic embryos was fast and efficient. The addition of 5-AzaC reduced the efficiency and productivity of SE and, as a result, only $5 \%$ of the explants could undergo SE induction. Since no signs of tissue lethality were observed in the treated cultures, it was hypothesized that the inhibition of SE was not a result of the toxic effect of 5-AzaC on cellular metabolism, but was a consequence of the impact associated with hypomethylation of DNA at the beginning of the process. 
Table 1. Techniques used to evaluate DNA methylation and the effect of methylation inhibitors on the somatic embryogenesis (SE) of different species of plants.

\begin{tabular}{|c|c|c|c|c|c|}
\hline Species & Family & $\begin{array}{c}\text { Detection of DNA } \\
\text { Methylation (Method) }\end{array}$ & $\begin{array}{l}\text { DNA Methylation } \\
\text { Inhibitor Used }\end{array}$ & Effects of Inhibitor & References \\
\hline \multirow[t]{2}{*}{ Acca sellowiana } & Myrtaceae & CRED-RA & NA & NA & [80] \\
\hline & & HPLC & 5-AzaC & $\begin{array}{l}\text { 5-AzaC }(50 \mu \mathrm{M}) \text { induced an increase in GDM and improved } \\
\text { the induction of SE. However, in the conversion phase, } \\
\text { somatic embryos had a deregulatory effect during the } \\
\text { formation of autotrophic plants, resulting in significantly } \\
\text { lower conversion rates }\end{array}$ & [81] \\
\hline Arabidopsis thaliana & Brassicaceae & ELISA & 5-AzaC & $\begin{array}{l}\text { Explants treated with } 5 \text {-AzaC }(10 \mu \mathrm{M}) \text { showed a drastic } \\
\text { inhibition of } \mathrm{SE} \text { and the explants produced massive } \\
\text { non-embryogenic callus, whereas in non-treated-explants } \\
\text { they formed somatic embryos quickly and efficiently }\end{array}$ & [34] \\
\hline Araucaria angustifolia & Araucariaceae & HPLC & NA & NA & [82] \\
\hline Bactris gasipaes & Arecaceae & HPLC & NA & NA & [83] \\
\hline $\begin{array}{c}\text { Brachypodium } \\
\text { distachyon }\end{array}$ & Poaceae & TUNEL & 5-AzaC & $\begin{array}{l}\text { At a concentration of } 50 \mu \mathrm{M} \text { of } 5 \text {-AzaC, induction of } \\
\text { embryogenic masses (EM) was totally inhibited, while in } 5 \\
\mu \mathrm{M} \text { of } 5 \text {-AzaC } 10 \% \text { of explants (zygotic embryos) } \\
\text { developed callus with EM. }\end{array}$ & {$[84]$} \\
\hline Brassica napus & Brassicaceae & ELISA & 5-AzaC & $\begin{array}{l}\text { Induction of embryos increased when explants were treated } \\
\text { four days in 5-AzaC }(2.5 \mu \mathrm{M}) \text {. In longer treatments with } \\
5 \text {-AzaC the formation of somatic embryos decreased }\end{array}$ & [78] \\
\hline Castanea sativa & Fagaceae & HPCE & NA & NA & [66] \\
\hline Citrus paradise & Rutaceae & MSAP & NA & NA & [85] \\
\hline \multirow[t]{2}{*}{ Coffea canephora } & Rubiaceae & HPLC & 5-AzaC & $\begin{array}{c}\text { Embryogenic process was strongly inhibited when 5-AzaC } \\
\text { was added earlier. However, this negative effect was not } \\
\text { observed when added to the } 35 \text { days post induction (dpi). } \\
\text { The effect of 5-AzaC }(20 \mu \mathrm{M}) \text { added at day } 21 \text { dpi not only } \\
\text { synchronized the embryogenic process but also reduced the } \\
\text { maturation of somatic embryos }\end{array}$ & {$[60]$} \\
\hline & & MSAP & NA & NA & [86] \\
\hline
\end{tabular}


Table 1. Cont.

\begin{tabular}{|c|c|c|c|c|c|}
\hline Species & Family & $\begin{array}{c}\text { Detection of DNA } \\
\text { Methylation (Method) }\end{array}$ & $\begin{array}{l}\text { DNA Methylation } \\
\text { Inhibitor Used }\end{array}$ & Effects of Inhibitor & References \\
\hline \multirow[t]{2}{*}{ Cucurbita pepo } & Cucurbitaceae & MSAP & 5-AzaC & $\begin{array}{l}\text { Addition of 5-AzaC }(12.3 \mu \mathrm{M}) \text { to the basal medium } \\
\text { (MSC) with or without 2,4-D did not significantly alter } \\
\text { the proportion of embryos in different stages } \\
\text { compared to that found in the same medium without } \\
\text { 5-AzaC. In the MSC medium with 2,4-D and 5-AzaC, } \\
\text { most embryos remained in the early stages of } \\
\text { development; however, some developed to more } \\
\text { mature stages }\end{array}$ & [87] \\
\hline & & CRED-RA/MSAP & 5-AzaC & $\begin{array}{c}\text { 5-AzaC had no effects (global DNA methylation or } \\
\text { capacities for the development and regeneration) on } \\
\text { embryogenic cultures }\end{array}$ & [88] \\
\hline \multirow[t]{4}{*}{ Daucus carota } & Apiaceae & HPLC & 5-AzaC/ECP & $\begin{array}{c}\text { When ECP is added, SE is immediately blocked. } \\
\text { Isolated mutant line that is resistant to the } \\
\text { hypomethylating activity of ECP and 5-AzaC shows a } \\
\text { higher level of endogenous indole acetic acid (IAA) } \\
\text { and a different metabolism of IAA, suggesting the } \\
\text { endogenous synthesis of IAA in the habituated tissue } \\
\text { could be the reason for its low sensitivity to } \\
\text { methylation inhibitors }\end{array}$ & [65] \\
\hline & & Immunodetection & 5-AzaC & $\begin{array}{l}\text { 5-AzaC suppresses embryogenesis but does not } \\
\text { prevent the proliferation of dedifferentiated cells from } \\
\text { cells in suspension. }\end{array}$ & [89] \\
\hline & & & 5-AzaC & $\begin{array}{c}\text { When 5-AzaC }(0.41 \mu \mathrm{M}) \text { was added to the medium, } \\
\text { somatic embryos were formed to the same extent as in } \\
\text { the control without 5-AzaC. When 5-AzaC }(20.5 \mu \mathrm{M}) \\
\text { was supplemented for } 3 \text { days after the } 24 \text {-hour } \\
\text { treatment with 2,4-D, the formation of somatic } \\
\text { embryos was severely inhibited }\end{array}$ & [90] \\
\hline & & HPLC & NA & NA & {$[62]$} \\
\hline Elaeis guineensis & Arecaceae & HPLC/MSAP & NA & NA & [91] \\
\hline
\end{tabular}


Table 1. Cont

\begin{tabular}{|c|c|c|c|c|c|}
\hline Species & Family & $\begin{array}{c}\text { Detection of DNA } \\
\text { Methylation (Method) }\end{array}$ & $\begin{array}{l}\text { DNA Methylation } \\
\text { Inhibitor Used }\end{array}$ & Effects of Inhibitor & References \\
\hline & & HPLC & NA & NA & [92] \\
\hline Eleuterococcus senticosus & Araliaceae & HPLC/MSAP & NA & NA & [93] \\
\hline Freesia hybrida & Iridaceae & MSAP & NA & NA & [94] \\
\hline Gentiana pannonica & Gentianaceae & HPLC & NA & NA & [95] \\
\hline \multirow[t]{4}{*}{ Hordeum vulgare } & Poaceae & MS-AFLP & NA & NA & [96] \\
\hline & & ELISA & NA & NA & [67] \\
\hline & & ELISA & 5-AzaC & $\begin{array}{l}\text { Induction of embryos increased with four days of treatment } \\
\text { with 5-AzaC }(2.5 \mu \mathrm{M}) \text {, the response was associated with a } \\
\text { decrease in DNA methylation. In contrast, longer 5-AzaC } \\
\text { treatments decreased embryo generation }\end{array}$ & [78] \\
\hline & & HPLC/MS-AFLP & NA & NA & [97] \\
\hline Laris $x$ eurolepis & Pinaceae & HPLC & 5-AzaC/Hydroxy-urea & $\begin{array}{l}\text { 5-AzaC }(100 \mu \mathrm{M}) \text { altered the overall DNA methylation } \\
\text { status of embryogenic cultures and significantly reduced } \\
\text { their relative growth rate and embryogenic potential }\end{array}$ & [98] \\
\hline Medicago truncatula & Fabaceae & MSAP & 5-AzaC & $\begin{array}{l}\text { 5-AzaC }(100 \mu \mathrm{M}) \text { stopped the generation of somatic } \\
\text { embryos in the embryogenic line and the proliferation of } \\
\text { callus in the non-embryogenic line. Analysis with } \\
\text { restriction enzymes sensitive to total DNA methylation } \\
\text { extracted from the untreated 5-AzaC-treated callus showed } \\
\text { a decrease in DNA methylation levels }\end{array}$ & [99] \\
\hline Ocotea catharinensis & Lauraceae & MSAP & NA & NA & [100] \\
\hline Pennisetum purpureum & Poaceae & HPLC/MSAP & NA & NA & [101] \\
\hline Picea omorika & Pinaceae & MS-RAPD & 5-AzaC & $\begin{array}{l}\text { DNA methylation decreased by } 19 \% \text { compared to the same } \\
\text { medium without 5-AzaC (12.3 } \mu \mathrm{M}) \text {. However, the total } \\
\text { number of embryos developed in the subsequent transfer to } \\
\text { the maturation medium was not significantly different (182 } \\
\text { and } 190 \text { somatic embryos, respectively) }\end{array}$ & [102] \\
\hline
\end{tabular}


Table 1. Cont

\begin{tabular}{|c|c|c|c|c|c|}
\hline Species & Family & $\begin{array}{c}\text { Detection of DNA } \\
\text { Methylation (Method) }\end{array}$ & $\begin{array}{l}\text { DNA Methylation } \\
\text { Inhibitor Used }\end{array}$ & Effects of Inhibitor & References \\
\hline Pinus nigra & Pinaceae & CRED-RA & NA & NA & [63] \\
\hline Pinus pinaster & Pinaceae & HPLC & 5-AzaC & $\begin{array}{l}\text { Embryonal masses grew when they were exposed } 9 \\
\text { days to 5-AzaC. Growth was inversely proportional to } \\
\text { the increase in drug concentration. The highest } \\
\text { amounts of somatic embryos were obtained at the } 10 \\
\text { and } 15 \mu \mathrm{m} \text { concentrations of } 5 \text {-AzaC, the treatments } \\
\text { with the highest levels of methylation }(19.5 \% \text { and } \\
21.3 \% \text {, respectively) }\end{array}$ & [77] \\
\hline Quercus alba & Fagaceae & ELISA & NA & NA & {$[64]$} \\
\hline Quercus suber & Fagaceae & HPCE/Immunolocalization & NA & NA & [103] \\
\hline Rosa hybrida & Rosaceae & MS-AFLP & NA & NA & [104] \\
\hline Solanum tuberosum & Solanaceae & MS-AFLP & NA & NA & [105] \\
\hline \multirow[t]{2}{*}{ Theobroma cacao } & Malvaceae & MSAP & NA & NA & {$[61]$} \\
\hline & & MSAP & NA & NA & [106] \\
\hline
\end{tabular}

GDM increased as SE proceeded and during the extended SE the aged somatic embryos could recover embryogenic potential when treated with 5-AzaC (20

$\mu \mathrm{M})$. The results of this study suggested that

long-term SE in cocoa induced a decrease in embryogenic potential, but that it could be reversed by 5 -AzaC supplementation

\begin{tabular}{|c|c|c|c|c|c|}
\hline Triticosecale & Poaceae & HPLC & NA & NA & [107] \\
\hline Vitis vinifera & Vitaceae & MSAP & NA & NA & [108] \\
\hline \multirow[t]{2}{*}{ Zea mays } & Poaceae & MSAP & NA & NA & [109] \\
\hline & & meDIP & NA & NA & [110] \\
\hline
\end{tabular}

5-AzaC 5-Azacytidine, CRED-RA Coupling of Restriction Enzyme and Random Amplification, ELISA Enzymatic-Linked Immunosorbent Assay, HPCE Hight-Performance Capillary Electrophoresis, HPLC High-Performance Liquid Chromatography, meDIP Methylated DNA Immunoprecipitation, MS-AFLP Methylation Sensitive-Amplification Fragment Length Polymorphism, MS-RAPD Methylation Sensitive-Random Amplification of Polymorphic DNA, MSAP Methyl-Sensitive Amplification Polymorphism, TUNEL Terminal deoxynucleotidyl transferase dUTP Nick End Labeling, ECP 2-amino-5-ethoxycarbonyl-pyrimidine-4 (3H), NA Not Applied. 


\section{5-AzaC and 2,4-D Can Work Together During SE}

There are important but contradictory studies that describe the effects of the application of 5-AzaC along with 2,4-D in SE protocols. For instance, the addition of $20.5 \mu \mathrm{M}$ of 5-AzaC $+4.52 \mathrm{mM}$ of 2,4-D in the first $24 \mathrm{~h}$ of the SE protocol in $D$. carota generated the same rate of somatic embryo formation as in the control (with the same concentration of 2,4-D but without 5-AzaC) at the end of the process (day 14) [90]. In the same study, it was reported that the formation of somatic embryos at day 14 was severely inhibited when 5-AzaC was applied (without 2,4-D) for three days after the 24-hour treatment. In Cucurbita pepo a similar result was reported: the addition of $12.3 \mu \mathrm{M}$ of 5-AzaC to the basal culture medium (MSC) + 2,4-D caused a statistically significant decrease in DNA methylation in the DEC line (producer of somatic embryos in early stages) and a non-significant reduction in the PEDC line (producer of pro-embryogenic cells). The HEC line (producer of an equal proportion of embryos in all different stages) showed a slight increase in the level of DNA methylation after the addition of 5-AzaC to MSC. The addition of 5-AzaC to MSC with or without 2,4-D did not significantly alter the proportion of embryos in different stages compared to that found in the same medium without 5-AzaC [87]. On the other hand, in Acca sellowiana, the effect of 5-AzaC and 2,4-D on GDM during SE showed that a pulse of 2,4-D $(200 \mu \mathrm{M})+\mathrm{AzaC}(50 \mu \mathrm{M})$ generates an increase in GDM and improves the induction of SE [81].

We broadly discussed above that auxins are hypermethylating substances, while 5-AzaC has a hypomethylating effect. However, because both substances have been used in different concentrations, in different proportions (2,4-D/5-AzaC) and at different times (without mentioning the difference between SE protocols and species studied), it is difficult to determine the optimal balance to obtain the greatest embryogenic potential in SE protocols. One aspect that we can highlight in the three studies cited above (D. carota, C. pepo, and A. sellowiana) is the moment where 5-AzaC was added. In C. pepo 5-AzaC was added to the medium where the embryogenic calluses already induced were established before they formed somatic embryos. In Acca sellowiana, 5-AzaC was added as a pretreatment and had positive effects on embryo generation. In the first two studies (D. carota and C. pepo) where 5-AzaC was added late to the process, the results were visibly adverse. On the other hand, in A. sellowiana, 5 -AzaC was added at the beginning of the process and had positive effects. This suggests that the time at which 5-AzaC is added is determining in the outcome of the process: the earlier it is added, the less negative the effects on SE will be.

Therefore, based on the SE systems in which the use of 5-AzaC is reported, one needs to do some preliminary experiments to ensure reproducible results with the literature. These are the most important:

- Test the effects of different concentrations of 5-AzaC to know the minimum levels to observe the differential impact and maximum concentrations so that they are not toxic to the explants.

- Select the timing of the process for adding the inhibitor, as the effect could make the embryogenic process more efficient or inhibit it, depending on whether 5-AzaC is applied before/during the induction or development of the somatic embryos.

- If the culture medium includes reagents that sequester substances, such as activated carbon [111], higher concentrations of the inhibitor should be applied than in culture media without this type of reagent. Another option is to use a pre-treatment with the inhibitor for a specific time and then transfer the explant to the conventional culture medium if it contains activated charcoal.

- Take into consideration the $\mathrm{pH}$ and temperature of the culture medium at the time the inhibitor is applied. It has been reported that $5-\mathrm{AzaC}$ is moderately stable in acidic solutions while rapidly decomposing in alkaline media and that degradation is accelerated dramatically with increasing temperature [112]. 
Based on all of the information previously discussed, we propose an optimal time to add 5-AzaC (Figure 4). Because there is a direct relationship between the development of SE and the levels of GDM, it is essential to know the three common phases in which GDM has the most significant influence. Before the SE induction process starts, explants exhibit elevated levels of GDM (probably due to the high concentrations of 2,4-D used in the culture media to induce SE, which also affects the endogenous production of ethylene and the SAM/SAH ratio [69]). Then, during the induction process (specifically in the phase of acquisition of embryogenic competence), GDM reaches its lowest levels in pro-embryogenic cells. Finally, GDM gradually increases from the phase of globular somatic embryos to the seedling phase. Thus, we can hypothesize that 5-AzaC addition could help to reduce GDM in the induction phase, promoting the establishment of an optimal level of methylation (mostly low). This would trigger in the explant cells the acquisition of embryogenic competence. As SE progressed, 5-AzaC would be assimilated and later degraded, so that the normal increase of GDM required for SE would follow its ordinary path in advanced developmental stages.

\section{Conclusions}

Low levels of DNA methylation are related to high embryogenic potential in explants during the induction of the SE. However, it is still necessary to generate more information on other SE protocols (by direct and indirect pathways) and make a more methodical comparison between mono- and dicotyledonous plants to corroborate this pattern.

When such SE studies are available, it would be beneficial to study the biochemical, molecular and epigenetic changes that accompany the acquisition or loss of morphogenic competence. In these protocols (as in the vast majority of protocols that have been reported over the years in various species), cultures need a high concentration of 2,4-D in the induction process. This auxin needs to be reduced (or totally removed) to promote the development of somatic embryos. Moreover, the 5-AzaC addition helps to reduce GDM in the induction phase, improving the establishment of an optimal level of methylation (low) to be carried out in the explant cells' acquisition of embryogenic competence. With the use of 5-AzaC in SE protocols, it is possible to demonstrate that DNA methylation plays a significant role in the acquisition of embryogenic competence of plant cells. In the near future, there will be more accurate information about cellular processes that are directly affected by DNA methylation during SE.

The DNA methylation level in several systems that have been used 5-AzaC to promote SE has been determined with different methods such as HPLC, ELISA, MSAP and others (Table 1). However, the selected methodology depends on the kind of DNA methylation to be analyzed and the information that is needed to answer a specific biological question. Each method can give information about DNA methylation such as global DNA methylation, regional DNA methylation, genome analysis, methylation analysis DNA sequencing, detection of particular methylation patterns and individual CpG analysis (Table 1) [21].

Author Contributions: Conceptualization, C.D.-1.-P. and P.O.-M.; Writing-Original Draft Preparation, P.O.-M.; Writing-Review \& Editing, C.D.-1.-P. and L.S.-C.; Supervision, C.D.-1.-P.; Project Administration, C.D.-1.-P.

Funding: This work was supported financially by a grant from Consejo Nacional De Ciencia Y Tecnologiaía (CONACYT) to C.D. (285898) and L.S.C. (129717), and a CONACYT-scholarship to P.O.M. (438057).

Acknowledgments: We want to thank Carlos Torrecilla-Rodríguez for the support in the graphic design of the images.

Conflicts of Interest: The authors declare no conflict of interest. 


\section{References}

1. Shahzad, A.; Sharma, S.; Parveen, S.; Saeed, T.; Shaheen, A.; Akhtar, R.; Yadav, V.; Upadhyay, A.; Ahmad, Z. Historical perspective and basic principles of plant tissue culture. In Plant Biotechnology: Principles and Applications; Springer: Singapore, Singapore, 2017; pp. 1-36.

2. Hussain, A.; Qarshi, I.A.; Nazir, H.; Ullah, I.; Leva, A.; Rinaldi, L. Recent advances in plant in vitro culture. Chapter 2012, 1, 1-28.

3. Von Arnold, S.; Sabala, I.; Bozhkov, P.; Dyachok, J.; Filonova, L. Developmental pathways of somatic embryogenesis. Plant Cell Tissue Organ Cult. 2002, 69, 233-249. [CrossRef]

4. Thorpe, T.A.; Stasolla, C. Somatic embryogenesis. In Current Trends in the Eembryology of Angiosperms; Springer: Dordrecht, The Netherlands, 2001; pp. 279-336.

5. Williams, E.; Maheswaran, G. Somatic embryogenesis: Factors influencing coordinated behaviour of cells as an embryogenic group. Ann. Bot. 1986, 57, 443-462. [CrossRef]

6. Jain, S.M.; Gupta, P. Step Wise Protocols for Somatic Embryogenesis of Important Woody Plants; Springer: Cham, Switzerland, 2018; pp. i-xvi.

7. Lee, K.; Seo, P.J. Dynamic Epigenetic Changes during Plant Regeneration. Trends Plant Sci. 2018. [CrossRef] [PubMed]

8. Loyola-Vargas, V.M. The History of somatic embryogenesis. In Somatic Embryogenesis: Fundamental Aspects and Applications; Springer: Cham, Switzerland, 2016; pp. 11-22.

9. Heringer, A.S.; Santa-Catarina, C.; Silveira, V. Insights from proteomic studies into plant somatic embryogenesis. Proteomics 2018, 18, 1700265. [CrossRef] [PubMed]

10. Góngora-Castillo, E.; Nic-Can, G.I.; Galaz-Ávalos, R.M.; Loyola-Vargas, V.M. Elaboration of Transcriptome During the Induction of Somatic Embryogenesis. In Plant Cell Culture Protocols; Humana Press: New York, NY, USA, 2018; pp. 411-427.

11. Fehér, A. Somatic embryogenesis-Stress-induced remodeling of plant cell fate. Biochim. Biophys. Acta 2015, 1849, 385-402. [CrossRef] [PubMed]

12. Jiménez, V.M. Involvement of Plant Hormones and Plant Growth Regulators on in vitro Somatic Embryogenesis. Plant Growth Regul. 2005, 47, 91-110. [CrossRef]

13. Zavattieri, M.A.; Frederico, A.M.; Lima, M.; Sabino, R.; Arnholdt-Schmitt, B. Induction of somatic embryogenesis as an example of stress-related plant reactions. Electron. J. Biotechnol. 2010, 13, 12-13. [CrossRef]

14. Karami, O.; Aghavaisi, B.; Mahmoudi Pour, A. Molecular aspects of somatic-to-embryogenic transition in plants. J. Chem. Biol. 2009, 2, 177-190. [CrossRef] [PubMed]

15. Elhiti, M.; Stasolla, C.; Wang, A. Molecular regulation of plant somatic embryogenesis. In Vitro Cell. Dev. Biol. Plant 2013, 49, 631-642. [CrossRef]

16. Verdeil, J.-L.; Alemanno, L.; Niemenak, N.; Tranbarger, T.J. Pluripotent versus totipotent plant stem cells: Dependence versus autonomy? Trends Plant Sci. 2007, 12, 245-252. [CrossRef] [PubMed]

17. Toonen, M.A.; Hendriks, T.; Schmidt, E.D.; Verhoeven, H.A.; van Kammen, A.; de Vries, S.C. Description of somatic-embryo-forming single cells in carrot suspension cultures employing video cell tracking. Planta 1994, 194, 565-572. [CrossRef]

18. Fehér, A. Why somatic plant cells start to form embryos? In Somatic Embryogenesis; Springer: Berlin, Gerlin, 2005; pp. 85-101.

19. Mahdavi-Darvari, F.; Noor, N.M.; Ismanizan, I. Epigenetic regulation and gene markers as signals of early somatic embryogenesis. Plant Cell Tissue Organ Cult. 2015, 120, 407-422. [CrossRef]

20. Kumar, V.; Van Staden, J. New insights into plant somatic embryogenesis: An epigenetic view. Acta Physiol. Plant. 2017, 39, 194. [CrossRef]

21. De-la-Peña, C.; Nic-Can, G.I.; Galaz-Ávalos, R.M.; Avilez-Montalvo, R.; Loyola-Vargas, V.M. The role of chromatin modifications in somatic embryogenesis in plants. Front. Plant Sci. 2015, 6, 635. [CrossRef] [PubMed]

22. Bhojwani, S.S.; Razdan, M.K. Plant Tissue Culture: Theory and Practice; Elsevier: Amsterdam, The Netherlands, 1986; Volume 5, pp. 91-112. 
23. Karim, R.; Tan, Y.S.; Singh, P.; Khalid, N.; Harikrishna, J.A. Expression and DNA methylation of SERK, BBM, LEC2 and WUS genes in in vitro cultures of Boesenbergia rotunda (L.) Mansf. Physiol. Mol. Biol. Plants 2018, 24, 741-751. [CrossRef] [PubMed]

24. Karim, R.; Nuruzzaman, M.; Khalid, N.; Harikrishna, J. Importance of DNA and histone methylation in in vitro plant propagation for crop improvement: A review. Ann. Appl. Biol. 2016, 169, 1-16. [CrossRef]

25. Razin, A.; Riggs, A.D. DNA methylation and gene function. Science 1980, 210, 604-610. [CrossRef] [PubMed]

26. Taylor, S.M.; Jones, P.A. Mechanism of action of eukaryotic DNA methyltransferase: Use of 5-azacytosine-containing DNA. J. Mol. Biol. 1982, 162, 679-692. [CrossRef]

27. Jones, P.A.; Taylor, S.M. Cellular differentiation, cytidine analogs and DNA methylation. Cell 1980, 20, 85-93. [CrossRef]

28. Niwa, O.; Sugahara, T. 5-Azacytidine induction of mouse endogenous type C virus and suppression of DNA methylation. Proc. Natl. Acad. Sci. USA 1981, 78, 6290-6294. [CrossRef] [PubMed]

29. Hoffmann, J.; Steffen, D.; Gusella, J.; Tabin, C.; Bird, S.; Cowing, D.; Weinberg, R. DNA methylation affecting the expression of murine leukemia proviruses. J. Virol. 1982, 44, 144-157. [PubMed]

30. Groudine, M.; Eisenman, R.; Weintraub, H. Chromatin structure of endogenous retroviral genes and activation by an inhibitor of DNA methylation. Nature 1981, 292, 311-317. [CrossRef] [PubMed]

31. Hepburn, A.; Clarke, L.; Pearson, L.; White, J. The role of cytosine methylation in the control of nopaline synthase gene expression in a plant tumor. J. Mol. Appl. Genet. 1983, 2, 315-329. [PubMed]

32. Santi, D.V.; Garrett, C.E.; Barr, P.J. On the mechanism of inhibition of DNA-cytosine methyltransferases by cytosine analogs. Cell 1983, 33, 9-10. [CrossRef]

33. Li, J.; Wang, M.; Li, Y.; Zhang, Q.; Lindsey, K.; Daniell, H.; Jin, S.; Zhang, X. Multi-omics analyses reveal epigenomics basis for cotton somatic embryogenesis through successive regeneration acclimation (SRA) process. Plant Biotechnol. J. 2018. [CrossRef] [PubMed]

34. Grzybkowska, D.; Morończyk, J.; Wójcikowska, B.; Gaj, M.D. Azacitidine (5-AzaC)-treatment and mutations in DNA methylase genes affect embryogenic response and expression of the genes that are involved in somatic embryogenesis in Arabidopsis. Plant Growth Regul. 2018, 85, 243-256. [CrossRef]

35. Quiroz-Figueroa, F.R.; Rojas-Herrera, R.; Galaz-Avalos, R.M.; Loyola-Vargas, V.M. Embryo production through somatic embryogenesis can be used to study cell differentiation in plants. Plant Cell Tissue Organ Cult. 2006, 86, 285. [CrossRef]

36. Quiroz-Figueroa, F.; Fuentes-Cerda, C.; Rojas-Herrera, R.; Loyola-Vargas, V. Histological studies on the developmental stages and differentiation of two different somatic embryogenesis systems of Coffea arabica. Plant Cell Rep. 2002, 20, 1141-1149.

37. Birnbaum, K.D.; Roudier, F. Epigenetic memory and cell fate reprogramming in plants. Regeneration 2017, 4, 15-20. [CrossRef] [PubMed]

38. Ikeuchi, M.; Iwase, A.; Sugimoto, K. Control of plant cell differentiation by histone modification and DNA methylation. Curr. Opin. Plant Biol. 2015, 28, 60-67. [CrossRef] [PubMed]

39. Jullien, P.E.; Susaki, D.; Yelagandula, R.; Higashiyama, T.; Berger, F. DNA methylation dynamics during sexual reproduction in Arabidopsis thaliana. Curr. Biol. 2012, 22, 1825-1830. [CrossRef] [PubMed]

40. Diez, C.M.; Roessler, K.; Gaut, B.S. Epigenetics and plant genome evolution. Curr. Opin. Plant Biol. 2014, 18, 1-8. [CrossRef] [PubMed]

41. Matzke, M.A.; Mosher, R.A. RNA-directed DNA methylation: An epigenetic pathway of increasing complexity. Nat. Rev. Genet. 2014, 15, 394-408. [CrossRef] [PubMed]

42. Turck, F.; Coupland, G. Natural variation in epigenetic gene regulation and its effects on plant developmental traits. Evolution 2014, 68, 620-631. [CrossRef] [PubMed]

43. Zhong, X. Comparative epigenomics: A powerful tool to understand the evolution of DNA methylation. New Phytol. 2016, 210, 76-80. [CrossRef] [PubMed]

44. Vanyushin, B. Replicative DNA methylation in animals and higher plants. Curr. Top. Microbiol. Immunol. 1984, 108, 99-114. [PubMed]

45. Finnegan, E.; Kovac, K. Plant DNA methyltransferases. Plant Mol. Biol. 2000, 43, 189-201. [CrossRef] [PubMed]

46. Goll, M.G.; Bestor, T.H. Eukaryotic cytosine methyltransferases. Annu. Rev. Biochem. 2005, 74, 481-514. [CrossRef] [PubMed]

47. Bird, A. DNA methylation de novo. Science 1999, 286, 2287-2288. [CrossRef] [PubMed] 
48. Lindroth, A.M.; Cao, X.; Jackson, J.P.; Zilberman, D.; McCallum, C.M.; Henikoff, S.; Jacobsen, S.E. Requirement of CHROMOMETHYLASE3 for maintenance of CpXpG methylation. Science 2001, 292, 2077-2080. [CrossRef] [PubMed]

49. Law, J.A.; Jacobsen, S.E. Establishing, maintaining and modifying DNA methylation patterns in plants and animals. Nat. Rev. Genet. 2010, 11, 204-220. [CrossRef] [PubMed]

50. Du, J.; Zhong, X.; Bernatavichute, Y.V.; Stroud, H.; Feng, S.; Caro, E.; Vashisht, A.A.; Terragni, J.; Chin, H.G.; $\mathrm{Tu}, \mathrm{A}$. Dual binding of chromomethylase domains to H3K9me2-containing nucleosomes directs DNA methylation in plants. Cell 2012, 151, 167-180. [CrossRef] [PubMed]

51. Köhler, C.; Wolff, P.; Spillane, C. Epigenetic mechanisms underlying genomic imprinting in plants. Ann. Rev. Plant Biol. 2012, 63, 331-352. [CrossRef] [PubMed]

52. Finnegan, E.J.; Dennis, E.S. Isolation and identification by sequence homology of a putative cytosine methyltransferase from Arabidopsis thaliana. Nucleic Acids Res. 1993, 21, 2383-2388. [CrossRef] [PubMed]

53. Cokus, S.J.; Feng, S.; Zhang, X.; Chen, Z.; Merriman, B.; Haudenschild, C.D.; Pradhan, S.; Nelson, S.F.; Pellegrini, M.; Jacobsen, S.E. Shotgun bisulphite sequencing of the Arabidopsis genome reveals DNA methylation patterning. Nature 2008, 452, 215-219. [CrossRef] [PubMed]

54. Lister, R.; O'Malley, R.C.; Tonti-Filippini, J.; Gregory, B.D.; Berry, C.C.; Millar, A.H.; Ecker, J.R. Highly integrated single-base resolution maps of the epigenome in Arabidopsis. Cell 2008, 133, 523-536. [CrossRef] [PubMed]

55. Cao, X.; Springer, N.M.; Muszynski, M.G.; Phillips, R.L.; Kaeppler, S.; Jacobsen, S.E. Conserved plant genes with similarity to mammalian de novo DNA methyltransferases. Proc. Natl. Acad. Sci. USA 2000, 97, 4979-4984. [CrossRef] [PubMed]

56. He, X.-J.; Chen, T.; Zhu, J.-K. Regulation and function of DNA methylation in plants and animals. Cell Res. 2011, 21, 442-465. [CrossRef] [PubMed]

57. Milutinovic, S.; Zhuang, Q.; Niveleau, A.; Szyf, M. Epigenomic stress response knockdown of DNA methyltransferase 1 triggers an intra-S-phase arrest of DNA replication and induction of stress response genes. J. Biol. Chem. 2003, 278, 14985-14995. [CrossRef] [PubMed]

58. Berdasco, M.; Alcázar, R.; García-Ortiz, M.V.; Ballestar, E.; Fernández, A.F.; Roldán-Arjona, T.; Tiburcio, A.F.; Altabella, T.; Buisine, N.; Quesneville, H. Promoter DNA hypermethylation and gene repression in undifferentiated Arabidopsis cells. PLoS ONE 2008, 3, e3306. [CrossRef] [PubMed]

59. Li, W.; Liu, H.; Cheng, Z.J.; Su, Y.H.; Han, H.N.; Zhang, Y.; Zhang, X.S. DNA methylation and histone modifications regulate de novo shoot regeneration in Arabidopsis by modulating WUSCHEL expression and auxin signaling. PLoS Genet. 2011, 7, e1002243. [CrossRef] [PubMed]

60. Nic-Can, G.I.; López-Torres, A.; Barredo-Pool, F.; Wrobel, K.; Loyola-Vargas, V.M.; Rojas-Herrera, R.; De-la-Peña, C. New Insights into Somatic Embryogenesis: LEAFY COTYLEDON1, BABY BOOM1 and WUSCHEL-RELATED HOMEOBOX4 Are Epigenetically Regulated in Coffea canephora. PLoS ONE 2013, 8, e72160. [CrossRef] [PubMed]

61. Rodríguez López, C.M.; Wetten, A.C.; Wilkinson, M.J. Progressive erosion of genetic and epigenetic variation in callus-derived cocoa (Theobroma cacao) plants. New Phytol. 2010, 186, 856-868. [CrossRef] [PubMed]

62. Palmgren, G.; Mattsson, O.; Okkels, F.T. Specific levels of DNA methylation in various tissues, cell lines, and cell types of Daucus carota. Plant Physiol. 1991, 95, 174-178. [CrossRef] [PubMed]

63. Noceda, C.; Salaj, T.; Pérez, M.; Viejo, M.; Cañal, M.J.; Salaj, J.; Rodriguez, R. DNA demethylation and decrease on free polyamines is associated with the embryogenic capacity of Pinus nigra Arn. cell culture. Trees (Berl. West) 2009, 23, 1285-1293. [CrossRef]

64. Corredoira, E.; Cano, V.; Bárány, I.; Solís, M.-T.; Rodríguez, H.; Vieitez, A.-M.; Risueño, M.C.; Testillano, P.S. Initiation of leaf somatic embryogenesis involves high pectin esterification, auxin accumulation and DNA demethylation in Quercus alba. J. Plant Physiol. 2017, 213, 42-54. [CrossRef] [PubMed]

65. LoSchiavo, F.; Pitto, L.; Giuliano, G.; Torti, G.; Nuti-Ronchi, V.; Marazziti, D.; Vergara, R.; Orselli, S.; Terzi, M. DNA methylation of embryogenic carrot cell cultures and its variations as caused by mutation, differentiation, hormones and hypomethylating drugs. Theor. Appl. Genet. 1989, 77, 325-331. [CrossRef] [PubMed]

66. Viejo, M.; Rodríguez, R.; Valledor, L.; Pérez, M.; Cañal, M.J.; Hasbún, R. DNA methylation during sexual embryogenesis and implications on the induction of somatic embryogenesis in Castanea sativa Miller. Sex. Plant Reprod. 2010, 23, 315-323. [CrossRef] [PubMed] 
67. El-Tantawy, A.-A.; Solís, M.-T.; Risueño, M.C.; Testillano, P.S. Changes in DNA methylation levels and nuclear distribution patterns after microspore reprogramming to embryogenesis in barley. Cytogenet. Genome Res. 2014, 143, 200-208. [CrossRef] [PubMed]

68. Us-Camas, R.; Rivera-Solís, G.; Duarte-Aké, F.; De-la-Pena, C. In vitro culture: An epigenetic challenge for plants. Plant Cell Tissue Organ Cult. 2014, 118, 187-201. [CrossRef]

69. Von Aderkas, P.; Bonga, J.M. Influencing micropropagation and somatic embryogenesis in mature trees by manipulation of phase change, stress and culture environment. Tree Physiol. 2000, 20, 921-928. [CrossRef] [PubMed]

70. Ayil-Gutiérrez, B.; Galaz-Ávalos, R.M.; Peña-Cabrera, E.; Loyola-Vargas, V.M. Dynamics of the concentration of IAA and some of its conjugates during the induction of somatic embryogenesis in Coffea canephora. Plant Signal. Behav. 2013, 8, e26998. [CrossRef] [PubMed]

71. Munksgaard, D.; Mattsson, O.; Okkels, F.T. Somatic embryo development in carrot is associated with an increase in levels of S-adenosylmethionine, S-adenosylhomocysteine and DNA methylation. Physiol. Plant. 1995, 93, 5-10. [CrossRef]

72. Fki, L.; Kriaa, W.; Nasri, A.; Baklouti, E.; Chkir, O.; Masmoudi, R.B.; Rival, A.; Drira, N. Indirect somatic embryogenesis of date palm using juvenile leaf explants and low 2, 4-D concentration. In Date Palm Biotechnology Protocols Volume I; Humana Press: New York, NY, USA, 2017; pp. 99-106.

73. Steinmacher, D.A.; Heringer, A.S.; Jiménez, V.M.; Quoirin, M.G.; Guerra, M.P. Somatic Embryogenesis in Peach-Palm (Bactris gasipaes) Using Different Explant Sources. In Vitro Embryogenesis in Higher Plants; Humana Press: New York, NY, USA, 2016; pp. 279-288.

74. Moon, H.-K.; Lee, H.; Paek, K.-Y.; Park, S.-Y. Osmotic stress and strong 2, 4-D shock stimulate somatic-to-embryogenic transition in Kalopanax septemlobus (Thunb.) Koidz. Acta Physiol. Plant. 2015, 37, 1710. [CrossRef]

75. Ali, M.; Mujib, A.; Tonk, D.; Zafar, N. Plant regeneration through somatic embryogenesis and genome size analysis of Coriandrum sativum L. Protoplasma 2017, 254, 343-352. [CrossRef] [PubMed]

76. Wójcikowska, B.; Botor, M.; Morończyk, J.; Wójcik, A.M.; Nodzyński, T.; Karcz, J.; Gaj, M.D. Trichostatin A Triggers an Embryogenic Transition in Arabidopsis Explants via an Auxin-Related Pathway. Front. Plant Sci. 2018, 9, 1353. [CrossRef] [PubMed]

77. Klimaszewska, K.; Noceda, C.; Pelletier, G.; Label, P.; Rodriguez, R.; Lelu-Walter, M.A. Biological Characterization of Young and Aged Embryogenic Cultures of Pinus pinaster (Ait.). In Vitro Cell. Dev. Biol. Plant 2009, 45, 20-33. [CrossRef]

78. Solís, M.-T.; El-Tantawy, A.-A.; Cano, V.; Risueño, M.C.; Testillano, P.S. 5-azacytidine promotes microspore embryogenesis initiation by decreasing global DNA methylation, but prevents subsequent embryo development in rapeseed and barley. Front. Plant Sci. 2015, 6, 472. [CrossRef] [PubMed]

79. Quinga, L.A.P.; de Freitas Fraga, H.P.; do Nascimento Vieira, L.; Guerra, M.P. Epigenetics of long-term somatic embryogenesis in Theobroma cacao L.: DNA methylation and recovery of embryogenic potential. Plant Cell Tissue Organ Cult. 2017, 131, 295-305. [CrossRef]

80. Cristofolini, C.; do Nascimento Vieira, L.; de Freitas Fraga, H.P.; da Costa, I.R.; Guerra, M.P.; Pescador, R. DNA methylation patterns and karyotype analysis of off-type and normal phenotype somatic embryos of feijoa. Theor. Exp. Plant Physiol. 2014, 26, 217-224. [CrossRef]

81. Fraga, H.P.; Vieira, L.N.; Caprestano, C.A.; Steinmacher, D.A.; Micke, G.A.; Spudeit, D.A.; Pescador, R.; Guerra, M.P. 5-Azacytidine combined with 2, 4-D improves somatic embryogenesis of Acca sellowiana (O. Berg) Burret by means of changes in global DNA methylation levels. Plant Cell Rep. 2012, 31, 2165-2176. [CrossRef] [PubMed]

82. Fraga, H.P.; Vieira, L.N.; Heringer, A.S.; Puttkammer, C.C.; Silveira, V.; Guerra, M.P. DNA methylation and proteome profiles of Araucaria angustifolia (Bertol.) Kuntze embryogenic cultures as affected by plant growth regulators supplementation. Plant Cell Tissue Organ Cult. 2016, 125, 353-374. [CrossRef]

83. Heringer, A.S.; Steinmacher, D.A.; Fraga, H.P.F.; Vieira, L.N.; Ree, J.F.; Guerra, M.P. Global DNA methylation profiles of somatic embryos of peach palm (Bactris gasipaes Kunth) are influenced by cryoprotectants and droplet-vitrification cryopreservation. Plant Cell Tissue Organ Cult. 2013, 114, 365-372. [CrossRef]

84. Betekhtin, A.; Milewska-Hendel, A.; Chajec, L.; Rojek, M.; Nowak, K.; Kwasniewska, J.; Wolny, E.; Kurczynska, E.; Hasterok, R. 5-Azacitidine Induces Cell Death in a Tissue Culture of Brachypodium distachyon. Int. J. Mol. Sci. 2018, 19, 1806. [CrossRef] [PubMed] 
85. Hao, Y.; Wen, X.; Deng, X. Genetic and epigenetic evaluations of citrus calluses recovered from slow-growth culture. J. Plant Physiol. 2004, 161, 479. [CrossRef] [PubMed]

86. Landey, R.B.; Cenci, A.; Guyot, R.; Bertrand, B.; Georget, F.; Dechamp, E.; Herrera, J.-C.; Aribi, J.; Lashermes, P.; Etienne, H. Assessment of genetic and epigenetic changes during cell culture ageing and relations with somaclonal variation in Coffea arabica. Plant Cell Tissue Organ Cult. 2015, 122, 517-531. [CrossRef]

87. Leljak-Levanić, D.; Bauer, N.; Mihaljević, S.; Jelaska, S. Changes in DNA methylation during somatic embryogenesis in Cucurbita pepo L. Plant Cell Rep. 2004, 23, 120-127. [CrossRef] [PubMed]

88. Leljak-Levanić, D.; Mrvková, M.; Turečková, V.; Pěnčík, A.; Rolčík, J.; Strnad, M.; Mihaljević, S. Hormonal and epigenetic regulation during embryogenic tissue habituation in Cucurbita pepo L. Plant Cell Rep. 2016, 35, 77-89. [CrossRef] [PubMed]

89. Pedrali-Noy, G.; Bernacchia, G.; do Rosario Alvelos, M.; Cella, R. Daucus carota cells contain specific DNA methyltransferase inhibitors that interfere with somatic embryogenesis. Plant Biol. 2003, 5, 383-392. [CrossRef]

90. Yamamoto, N.; Kobayashi, H.; Togashi, T.; Mori, Y.; Kikuchi, K.; Kuriyama, K.; Tokuji, Y. Formation of embryogenic cell clumps from carrot epidermal cells is suppressed by 5-azacytidine, a DNA methylation inhibitor. J. Plant Physiol. 2005, 162, 47-54. [CrossRef] [PubMed]

91. Jaligot, E.; Rival, A.; Beulé, T.; Dussert, S.; Verdeil, J. Somaclonal variation in oil palm (Elaeis guineensis Jacq.): The DNA methylation hypothesis. Plant Cell Rep. 2000, 19, 684-690. [CrossRef]

92. Rival, A.; Ilbert, P.; Labeyrie, A.; Torres, E.; Doulbeau, S.; Personne, A.; Dussert, S.; Beulé, T.; Durand-Gasselin, T.; Tregear, J.W. Variations in genomic DNA methylation during the long-term in vitro proliferation of oil palm embryogenic suspension cultures. Plant Cell Rep. 2013, 32, 359-368. [CrossRef] [PubMed]

93. Chakrabarty, D.; Yu, K.-W.; Paek, K.Y. Detection of DNA methylation changes during somatic embryogenesis of Siberian ginseng (Eleuterococcus senticosus). Plant Sci. 2003, 165, 61-68. [CrossRef]

94. Gao, X.; Yang, D.; Cao, D.; Ao, M.; Sui, X.; Wang, Q.; Kimatu, J.; Wang, L. In vitro micropropagation of Freesia hybrida and the assessment of genetic and epigenetic stability in regenerated plantlets. J. Plant Growth Regul. 2010, 29, 257-267. [CrossRef]

95. Fiuk, A.; Bednarek, P.T.; Rybczyński, J.J. Flow cytometry, HPLC-RP, and metAFLP analyses to assess genetic variability in somatic embryo-derived plantlets of Gentiana pannonica Scop. Plant Mol. Biol. Rep. 2010, 28, 413-420. [CrossRef]

96. Bednarek, P.T.; Orłowska, R.; Koebner, R.M.; Zimny, J. Quantification of the tissue-culture induced variation in barley (Hordeum vulgare L.). BMC Plant Biol. 2007, 7, 10. [CrossRef] [PubMed]

97. Orłowska, R.; Machczyńska, J.; Oleszczuk, S.; Zimny, J.; Bednarek, P.T. DNA methylation changes and TE activity induced in tissue cultures of barley (Hordeum vulgare L.). J. Biol. Res. (Thessalon) 2016, 23, 19. [CrossRef] [PubMed]

98. Teyssier, C.; Maury, S.; Beaufour, M.; Grondin, C.; Delaunay, A.; Le Metté, C.; Ader, K.; Cadene, M.; Label, P.; Lelu-Walter, M.A. In search of markers for somatic embryo maturation in hybrid larch (Larix $\times$ eurolepis): Global DNA methylation and proteomic analyses. Physiol. Plant. 2014, 150, 271-291. [CrossRef] [PubMed]

99. Santos, D.; Fevereiro, P. Loss of DNA methylation affects somatic embryogenesis in Medicago truncatula. Plant Cell Tissue Organ Cult. 2002, 70, 155-161. [CrossRef]

100. Hanai, L.R.; Floh, E.I.S.; Fungaro, M.H.P.; Santa-Catarina, C.; de Paula, F.M.; Viana, A.M.; Vieira, M.L.C. Methylation patterns revealed by MSAP profiling in genetically stable somatic embryogenic cultures of Ocotea catharinensis (Lauraceae). In Vitro Cell. Dev. Biol. Plant 2010, 46, 368-377. [CrossRef]

101. Morrish, F.M.; Vasil, I.K. DNA methylation and embryogenic competence in leaves and callus of napiergrass (Pennisetum purpureum Schum.). Plant Physiol. 1989, 90, 37-40. [CrossRef] [PubMed]

102. Leljak-Levanic, D.; Mihaljevic, S.; Jelaska, S. Variations in DNA methylation in Picea omorika (Panc) purk. Embryogenic tissue and the ability for embryo maturation. Propag. Ornam. Plants 2009, 9, 3-9.

103. Pérez, M.; Viejo, M.; LaCuesta, M.; Toorop, P.; Cañal, M.J. Epigenetic and hormonal profile during maturation of Quercus suber L. somatic embryos. J. Plant Physiol. 2015, 173, 51-61. [CrossRef] [PubMed]

104. Xu, M.; Li, X.; Korban, S.S. DNA-methylation alterations and exchanges during in vitro cellular differentiation in rose (Rosa hybrida L.). Theor. Appl. Genet. 2004, 109, 899-910. [CrossRef] [PubMed] 
105. Sharma, S.K.; Bryan, G.J.; Winfield, M.O.; Millam, S. Stability of potato (Solanum tuberosum L.) plants regenerated via somatic embryos, axillary bud proliferated shoots, microtubers and true potato seeds: A comparative phenotypic, cytogenetic and molecular assessment. Planta 2007, 226, 1449-1458. [CrossRef] [PubMed]

106. Adu-Gyamfi, R.; Wetten, A.; Lopez, C.M.R. Effect of cryopreservation and post-cryopreservation somatic embryogenesis on the epigenetic fidelity of cocoa (Theobroma cacao L.). PLoS ONE 2016, 11, e0158857. [CrossRef] [PubMed]

107. Machczyńska, J.; Orłowska, R.; Mańkowski, D.R.; Zimny, J.; Bednarek, P.T. DNA methylation changes in triticale due to in vitro culture plant regeneration and consecutive reproduction. Plant Cell Tissue Organ Cult. 2014, 119, 289-299. [CrossRef]

108. Schellenbaum, P.; Mohler, V.; Wenzel, G.; Walter, B. Variation in DNA methylation patterns of grapevine somaclones (Vitis vinifera L.). BMC Plant Biol. 2008, 8, 78. [CrossRef] [PubMed]

109. Kaeppler, S.; Phillips, R. Tissue culture-induced DNA methylation variation in maize. Proc. Natl. Acad. Sci. USA 1993, 90, 8773-8776. [CrossRef] [PubMed]

110. Stelpflug, S.C.; Eichten, S.R.; Hermanson, P.J.; Springer, N.M.; Kaeppler, S.M. Consistent and heritable alterations of DNA methylation are induced by tissue culture in maize. Genetics 2014, 198, 209-218. [CrossRef] [PubMed]

111. Sáenz, L.; Herrera-Herrera, G.; Uicab-Ballote, F.; Chan, J.L.; Oropeza, C. Influence of form of activated charcoal on embryogenic callus formation in coconut (Cocos nucifera). Plant Cell Tissue Organ Cult. 2010, 100, 301-308. [CrossRef]

112. Argemí, A.; Saurina, J. Study of the degradation of 5-azacytidine as a model of unstable drugs using a stopped-flow method and further data analysis with multivariate curve resolution. Talanta 2007, 74, 176-182. [CrossRef] [PubMed]

(C) 2018 by the authors. Licensee MDPI, Basel, Switzerland. This article is an open access article distributed under the terms and conditions of the Creative Commons Attribution (CC BY) license (http://creativecommons.org/licenses/by/4.0/). 